\title{
Maintenance or stimulation of steroidogenic enzymes and testosterone production in rat Leydig cells by continuous and pulsatile infusions of luteinizing hormone during passive immunization against gonadotrophin-releasing hormone
}

\author{
D. J. Chase, J. A. Karle and R. E. Fogg \\ Department of Biological Sciences, State University of New York, Binghamton, \\ NY 13902-6000, USA
}

Summary. The importance of the pulsatility of luteinizing hormone (LH) secretion in maintaining key enzymes in the testosterone biosynthetic pathway in Leydig cells was studied using rats in which $\mathrm{LH}$ secretion was suppressed by passive immunization against gonadotrophin-releasing hormone $(\mathrm{GnRH})$ and replaced by continuous or pulsatile i.v. infusions of exogenous $\mathrm{LH}$, all delivering the same daily dose of the hormone (300 ng per $100 \mathrm{~g}$ NIDDK-ovine LH-24). Continuous infusions ( $12 \cdot 5 \mathrm{ng}$ per $100 \mathrm{~g} \mathrm{~h}^{-1}$ ) were compared with infusions of 1 min pulses every $2 \mathrm{~h}(25 \mathrm{ng}$ per $100 \mathrm{~g})$ and every $4 \mathrm{~h}(50 \mathrm{ng}$ per $100 \mathrm{~g})$. After 5 days of treatment in vivo with sheep anti-GnRH serum (or normal sheep serum) and LH (or vehicle), Leydig cells were purified and assayed in vitro for maximum production of testosterone stimulated by human chorionic gonadotrophin (hCG) and supported by 25 -hydroxycholesterol and for the activities of cholesterol side-chain cleavage, $\Delta^{5}-3 \beta$-hydroxysteroid dehydrogenase$\Delta^{5-4}$-isomerase ( $3 \beta$-HSD-isomerase) and $17 \alpha$-hydroxylase. Relative contents of cholesterol side-chain cleavage and $17 \alpha$-hydroxylase were also quantified by western and immunoblotting analysis. Activity of $3 \beta$-HSD-isomerase was reduced by about $40 \%$ by anti-GnRH treatment and was increased by all $\mathrm{LH}$ regimens in anti-GnRH-treated animals, with no consistent pattern in the effects of the different $\mathrm{LH}$ regimens. Results for testosterone-producing capacity and the other two enzymes differed in several respects. Treatment with anti-GnRH serum markedly reduced basal, hCG-stimulated and 25-hydroxycholesterol-supported testosterone production (by $80-90 \%$ ) and the activities of cholesterol side-chain cleavage (about $80 \%$ ) and $17 \alpha$-hydroxylase (about $65 \%$ ). Infusion of exogenous LH in any of the regimens tested prevented these changes or increased the activities to values greater than those in normal serum-treated controls. Differences in immunodetectable contents of the two enzymes generally paralleled those in enzyme activities. There was a consistent trend in the effects of $\mathrm{LH}$ replacement regimens on these parameters of steroidogenic activity: continuous infusions were more effective than pulses at $2 \mathrm{~h}$ intervals and these in turn were more effective than pulses at $4 \mathrm{~h}$ intervals, suggesting that the frequency of $\mathrm{LH}$ exposure is more important than the amplitude of individual exposures in maintaining Leydig cell steroidogenic function. Consistent differences among groups in hCG-stimulated relative to 25-hydroxycholesterol-supported testosterone production suggest that some constituents of Leydig cells prior to cholesterol side-chain cleavage enzyme are more sensitive to LH withdrawal and deviations from 'optimal' $\mathbf{L H}$ exposure than are the side-chain cleavage and subsequent enzymes in the testosterone biosynthetic pathway. 


\section{Introduction}

The steroidogenic capacity of testicular Leydig cells is normally maintained by exposure to pulsatile secretion of luteinizing hormone (LH). Previous studies in our laboratory have shown, however, that maintenance of the steroidogenic capacity of Leydig cells does not depend on the cells being exposed to the hormone intermittently, as they are normally by pulsatile LH secretion (Chase et al., 1988; Gibson-Berry \& Chase, 1990). In adult rats, for example, continuous intravenous infusions of $\mathrm{LH}$ were as effective as pulsatile infusions of the same daily dose (given as a series of $1 \mathrm{~min}$ pulses at intervals of $2 \mathrm{~h}$ ) in preventing the reduction in steroidogenic capacity of Leydig cells following suppression of LH secretion by passive immunization against gonadotrophin-releasing hormone (GnRH) (Gibson-Berry \& Chase, 1990). The fact that changes in production of testosterone supported by 25 -hydroxycholesterol paralleled those in testosterone production stimulated by human chorionic gonadotrophin (hCG) or cyclic AMP suggested that the changes were associated with changes in the activities of enzymes catalysing conversion of cholesterol to testosterone. The present studies used the same model to study regulation of the activities and contents of three of these enzymes: (i) cholesterol side-chain cleavage, the mitochondrial cytochrome P-450 enzyme that catalyses conversion of cholesterol to pregnenolone (commonly designated as $\mathrm{P}-450_{\mathrm{scC}}$ ); (ii) $3 \beta$-hydroxysteroid dehydrogenase- $\Delta^{5-4}$-isomerase

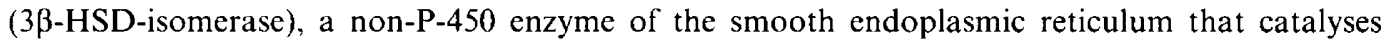
conversion of pregnenolone to progesterone; and (iii) 17a-hydroxylase, a cytochrome P-450 localized in the smooth endoplasmic reticulum that catalyses conversion of progesterone to $17 \alpha-$ hydroxyprogesterone (commonly designated as $\mathrm{P}-450_{17 \alpha}$ ). Biochemical, cloning and transfection studies have indicated that the single protein $\mathrm{P}-450_{17 \mu}$ catalyses the 17,20-lyase reaction, as well as the hydroxylation, to form androstenedione (reviewed by Hall, 1986 and Waterman \& Simpson, 1989).

Most studies indicate that all these enzymes are dependent on LH for maintenance of normal activity in Leydig cells (e.g. Samuels \& Helmreich, 1956; Menon et al., 1967; Shikita \& Hall, 1967; Purvis et al., 1973a, b; Murono \& Payne, 1979; Shaw et al., 1979; O'Shaughnessy \& Payne, 1982; Ewing et al., 1983), but there are several exceptions. Results by Ewing et al. have suggested that $3 \beta$-HSD-isomerase is less dependent on LH than are the other enzymes: the ability of whole perfused rat testes to produce progesterone from pregnenolone was unaffected by 10 days of $\mathrm{LH}$ withdrawal by either hypophysectomy or subcutaneous implants of testosterone and oestradiol (Wing et al., 1985) and was reduced by only $75 \%$ after 16 weeks of treatment with the steroid implants (Keeney et al., 1988). Payne and colleagues have reported that the content of P-450 $0_{\text {scC }}$ protein as well as its rate of de novo synthesis and the content of its mRNA are maintained constitutively at high values in mouse Leydig cells cultured in the absence of LH or cAMP (Anakwe \& Payne, 1987; Hales \& Payne, 1989). Although there are these conflicting results on the degree to which the enzymes are strictly dependent on LH, there seems to be no dispute among the reports cited that the gonadotrophin can increase the activities of all three enzymes.

The present studies examined the LH dependence of the three enzymes in the in vivo model in which LH secretion is suppressed by passive immunization against $\mathrm{GnRH}$, and determined whether the mode of LH administration (continuous versus pulsatile) in this model influences the response of any of the enzymes to the hormone. Experiments also compared testosterone production stimulated by gonadotrophin and supported by exogenous substrate in vitro as an indication of differential effects of in vivo treatments on constituents prior to these enzymes compared with effects on the enzymes themselves.

\section{Materials and Methods}

\section{Animals, anti-GnRH immunizations and $\mathrm{LH}$ infusions}

Young adult Sprague-Dawley rats (3-4 months old) were housed under a photoperiod of $12 \mathrm{~h}$ of light and $12 \mathrm{~h}$ of darkness and given Purina rat chow and water ad libitum. All experimental treatments were for 5 days. Two days 
before the beginning of the experiment, intra-atrial cannulae of Silastic tubing were inserted through the right internal jugular vein, brought out through the back of the neck and connected to automatic infusion pumps with custom-made Teflon-brass swivels, as described by Gibson-Berry \& Chase (1990). Surgical anaesthesia was achieved with i.m. injections of ketamine-HCl $\left(50 \mathrm{mg} \mathrm{kg}^{-1}\right)$ and xylazine $\left(10 \mathrm{mg} \mathrm{kg}^{-1}\right)$ and rats were given $60000 \mathrm{iu}$ penicillin-G (procain salt) i.m. to prevent infection. After surgery and throughout the experiment. drinking water was supplemented with aspirin ( $\left.40 \mathrm{mg} \mathrm{l}^{-1}\right)$ to inhibit clotting of the cannulae.

Rats were treated with sheep anti-GnRH serum (Chase et al., 1988) to suppress endogenous LH secretion (or with normal sheep serum) and infused with exogenous LH (or vehicle) for 5 days. The antiserum used in these studies was from a single bleeding of a single ram and was of high titre, binding about $60 \%$ of ${ }^{125} \mathrm{I}$-labelled $\mathrm{GnRH}\left(100 \mathrm{pmol} \mathrm{l}^{-1}\right)$ at a final dilution of 1:100 000. (See Chase et al., 1988, for descriptions of GnRH radioiodination, binding assay, etc.) Rats were given $2 \mathrm{ml}$ of antiserum through intra-atrial cannulae on the first day of the experiment, and $1 \mathrm{ml}$ every day thereafter. Pilot studies showed that this regimen effectively suppressed endogenous LH secretion, as serum testosterone was always reduced to castrate concentrations within several hours of the first antiserum infusion and was still at those concentrations immediately before any subsequent antiserum infusion. Control rats received the same regimen of infusions of normal sheep serum.

Starting $2 \mathrm{~h}$ after the first serum infusion, antiserum-treated rats were infused through the intra-atrial cannulae with vehicle (Krebs'-Ringer containing $0.5 \mathrm{mg}$ glucose $\mathrm{ml}^{-1}, 20$ iu heparin $\mathrm{ml}^{-1}$ and $1 \mathrm{mg}$ bovine serum albumin (BSA) $\mathrm{ml}^{-1}, \mathrm{pH} \mathrm{7 \cdot 2)}$ or with NIDDK ovine LH-24 (biological potency $=2 \cdot 3 \times \mathrm{NIH} \mathrm{LH} \mathrm{S1}$ ) in vehicle at a total daily dose of $300 \mathrm{ng}$ per $100 \mathrm{~g}$, given as continuous infusions (at $12.5 \mathrm{ng}$ per $100 \mathrm{~g} \mathrm{~h}^{-1}$ ) or as discontinuous infusions of $1 \mathrm{~min}$ pulses at intervals of $2 \mathrm{~h}(25 \mathrm{ng}$ per $100 \mathrm{~g})$ or $4 \mathrm{~h}(50 \mathrm{ng}$ per $100 \mathrm{~g})$. Rats treated with normal sheep serum were infused with vehicle given as pulses every $2 \mathrm{~h}$. All rats received the equivalent of $0 \cdot 1 \mathrm{ml}$ of vehicle $\mathrm{h}^{-1}$. All infusions were delivered by means of electronic infusion pumps equipped with antisyphoning restraints to prevent syringe plungers from advancing unless the pumps were running. For pulsatile regimens, pumps were controlled by automatic timers customized to provide precise durations of 'on' events using appropriate circuits and relays. Fresh LH solutions were prepared every other day from frozen aliquots of a concentrated stock solution ( $20 \mathrm{mg} \mathrm{LH}$ $\mathrm{ml}^{-1}$ Dulbecco's phosphate-buffered saline containing $10 \mathrm{mg} \mathrm{BSA} \mathrm{ml}^{-1}$ ). Rats were killed 5 days after the start of treatment, at the time of the next scheduled pulse of LH (or vehicle) or immediately after cessation of continuous infusions.

\section{Purification of Leydig cells}

Testes were dissociated by incubation with collagenase $\left(1 \mathrm{mg} \mathrm{ml}^{-1}\right)$ in tissue culture medium 199 (TCM199) + $10 \mathrm{mmol}$ Hepes $1^{-1}+0 \cdot 5 \% \mathrm{BSA}$, and Leydig cells were purified by Percoll gradient centrifugation, as described by Gibson-Berry \& Chase (1990). Final purified cell suspensions contained $70-80 \%$ Leydig cells as identified by histochemical staining for $3 \beta$-hydroxysteroid dehydrogenase (after Payne et al., 1980). Final cell suspensions were in a $1: 1$ mixture of Dulbecco's modified Eagle's medium:Ham's F12 +10 mmol Hepes $1^{-1}+0 \cdot 1 \%$ BSA (DME:F12); this was used (rather than TCM199) so that the incubation medium in cholesterol side-chain cleavage assays would be devoid of exogenous cholesterol.

\section{Testosterone production in vitro}

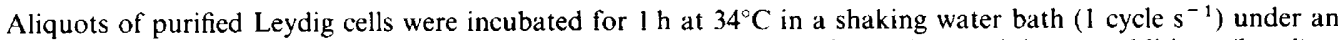
atmosphere of $95 \% \mathrm{O}_{2}: 5 \% \mathrm{CO}_{2}$. Incubations were in a total volume of $1.0 \mathrm{ml}$, containing no additions (basal), a maximally stimulatory concentration of hCG $\left(50 \mathrm{miu} \mathrm{ml} \mathrm{m}^{-1}\right)$, or a saturating concentration of 25 -hydroxycholesterol $\left(10 \mathrm{nmol} \mathrm{ml}{ }^{-1}\right)$, made up with $0.1 \mathrm{ml}$ of cell suspension in DME:F12 and $0.9 \mathrm{ml}$ of TCM $199+10 \mathrm{mmol} \mathrm{Hepes} 1{ }^{1}+$ $0 \cdot\left[\%\right.$ BSA. Dimethylsulfoxide $\left(7 \mu \mathrm{ml}^{-1}=100 \mu \mathrm{mol} \mathrm{l}^{-1}\right)$ was included to solubilize 25 -hydroxycholesterol. This analogue was used because it can serve as substrate for testosterone production independently of the cyclic-AMPdependent mechanisms that transport the endogenous substrate cholesterol to the mitochondria and increase its association with cholesterol side-chain cleavage enzyme (Toaff et al.. 1979, 1982; Georgiou \& Payne, 1985; Quinn et al. 1985). Incubations were terminated by chilling samples to $4 \mathrm{C}$, samples were centrifuged ( $1000 \mathrm{~g}$ for $20 \mathrm{~min}$ ) and supernatants were decanted and assayed for testosterone by radioimmunoassay (Gibson-Berry \& Chase, 1990).

\section{Enzyme activity assays}

For assays of $17 \alpha$-hydroxylase and $3 \beta$-HSD-isomerase, Leydig cells were disrupted by ultrasonication and incubated for $5 \mathrm{~min}$ at $37^{\circ} \mathrm{C}$ with saturating concentrations of $\left[1,2-{ }^{3} \mathrm{H}\right]$-progesterone $\left(2 \mu \mathrm{mol} 1^{-1}\right)$ and $\mathrm{NADPH}$ $\left(0.5 \mathrm{mmol} \mathrm{l}^{-1}\right)$ and with saturating concentrations of $\left[1,2{ }^{3} \mathrm{H}\right]$-pregnenolone $\left(2 \mu \mathrm{moll}^{-1}\right)$ and $\mathrm{NAD}\left(0.5 \mathrm{mmol} \mathrm{l}^{-1}\right)$, respectively, essentially as described by O'Shaughnessy et al. (1981) and O'Shaughnessy \& Payne (1982). Incubations were in a total volume of $1.0 \mathrm{ml}$, made up with $0.1 \mathrm{ml}$ of disrupted cell suspension in DME:F12 and $0.9 \mathrm{ml}$ of $0.05 \mathrm{~mol}$ potassium phosphate-buffered saline $1^{-1}\left(0.15 \mathrm{~mol} \mathrm{NaCl} 1^{-1}\right), \mathrm{pH} 7 \cdot 4$, containing 0.05 ml dimethylsulfoxide (to solubilize substrates) and appropriate concentrations of substrate and cofactor. Incubations were terminated by 
adding $0 \cdot 1 \mathrm{ml}$ of $\mathrm{NaOH}\left(1 \mathrm{moll}^{-1}\right)$ and chilling to $4^{\circ} \mathrm{C}$. Blanks, in which enzyme activity was inhibited by addition of $\mathrm{NaOH}$ before addition of disrupted cells, were included with each assay. Appropriate carriers $(25 \mu \mathrm{g})$ and ${ }^{14} \mathrm{C}$-labelled recovery standards (600-800 d.p.m.) were added: 17a-hydroxyprogesterone, androstenedione and testosterone in the case of $17 \alpha$-hydroxylase, and progesterone in the case of $3 \beta$-HSD-isomerase. Samples were extracted with $10 \mathrm{ml}$ of toluene, extracts were evaporated and redissolved in methanol, and products and substrates were separated by thinlayer chromatography. The solvent systems were benzene:ethyl acetate $(2: 1, \mathrm{v}: \mathrm{v})$ for the $17 \alpha$-hydroxylase assay, and chloroform:diethyl ether $(7: 1, \mathrm{v}: \mathrm{v})$ for the $3 \beta$-HSD-isomerase assay. In the former assay, the only product consistently above blank values was $17 \alpha$-hydroxyprogesterone; all results are expressed, therefore, in terms of this product alone. The spot corresponding to this product was eluted with methanol and subjected to a second chromatography (after addition of additional carrier progesterone) to minimize contamination with reaction substrate. The only product in the $3 \beta$-HSD-isomerase assay was progesterone. Content of $\left[{ }^{3} \mathrm{H}\right]$-products in thin-layer chromatograms was quantified by liquid scintillation spectrometry and corrected by recovery of ${ }^{14} \mathrm{C}$-labelled recovery standards.

Cholesterol side-chain cleavage activity was assayed by incubating intact cells for $1 \mathrm{~h}$ at $34^{\circ} \mathrm{C}$ under $95 \% \mathrm{O}_{2}: 5 \%$ $\mathrm{CO}_{2}$ with a saturating concentration of $\left[26,27{ }^{3} \mathrm{H}\right]-25$-hydroxycholesterol $\left(10 \mu \mathrm{mol} 1^{-1}\right)$ and determining $\left[{ }^{3} \mathrm{H}\right]-$ isocaproic acid, as described by Georgiou et al. (1987). Incubations were in a total volume of 1.0 ml of DME:F12, made up of $0.1 \mathrm{ml}$ of cell suspension and $0.9 \mathrm{ml}$ of medium containing substrate and $7 \mu 1$ of dimethylsulfoxide $\left(100 \mu \mathrm{mol}^{-1}\right)$ to solubilize the substrate. Incubations were terminated by adding $0.1 \mathrm{ml}$ of $\mathrm{NaOH}\left(1 \mathrm{~mol}^{-1}\right)$ and chilling to $4{ }^{\circ} \mathrm{C}$, and $0.1 \mathrm{ml}$ of $\left[{ }^{14} \mathrm{C}\right]$-caproic acid in $\mathrm{H}_{2} \mathrm{O}$ was added to monitor recovery of product. Samples were centrifuged ( $1000 \mathrm{~g}$ for $20 \mathrm{~min}$ ), supernatants were decanted, pellets were washed with $1.0 \mathrm{ml}$ of basified medium and recentrifuged, and these supernatants were combined with those from the first centrifugation. Supernatants were extracted with $10 \mathrm{ml}$ of chloroform (to remove unreacted substrate) and aliquots $(1.5 \mathrm{ml})$ of aqueous phases were mixed with aluminium oxide $\left(0.8 \mathrm{~g}\right.$, to extract more unreacted substrate). Content of $\left[{ }^{3} \mathrm{H}\right]$-isocaproic acid was determined by liquid scintillation spectrometry of aliquots $(0.4 \mathrm{ml})$ of the final aqueous phases, and corrected by recovery of $\left[{ }^{14} \mathrm{C}\right]$-caproic acid. This method of determining cholesterol side-chain cleavage activity has been thoroughly validated for rat Leydig cells by confirming that results are the same when activity is measured as the formation of $\left[16,17-{ }^{3} \mathrm{H}\right]$-pregnenolone and -progesterone from $\left[16,17-{ }^{3} \mathrm{H}\right]-25$-hydroxycholesterol or the formation of pregnenolone and progesterone (measured by radioimmunoassay) from 25-hydroxycholesterol, in the presence of the 17a-hydroxylase inhibitor SU-10603 in both cases (Georgiou et al., 1987).

\section{Electrophoresis, western blotting and immunoblotting analysis of enzyme content}

Aliquots of purified celts were washed twice with 0.01 mol sodium-phosphate-buffered saline (NaPBS) $1^{-1}$, using $15 \mathrm{~min}$ centrifugations at $500 \mathrm{~g}$ to pellet cells. Final cell pellets were lysed with $1 \%$ cholate and $0 \cdot 1 \%$ sodium dodecyl sulfate (SDS) in NaPBS $\left(6 \times 10^{6}\right.$ cells $\left.\mathrm{ml}^{-1}\right)$ and stored at $-20^{\circ} \mathrm{C}$ for polyacrylamide gel electrophoresis (PAGE). Lysates were denatured by adding 0.5 volume of $6 \%$ SDS $+100 \mathrm{mmol}$ dithiothreitol $1^{-1}+25 \%$ sucrose $+0.02 \%$ bromphenol blue in NaPBS and heating in boiling water for $15 \mathrm{~min}$. Volumes of sample representing 60000 and 100000 Leydig cells were subjected to electrophoresis in $10 \%$ polyacrylamide gels for $17 \alpha$-hydroxylase (P-450 $17 \alpha$ ) and cholesterol side-chain cleavage enzyme ( $\left.\mathrm{P}-450_{\mathrm{scc}}\right)$, respectively. Proteins were transferred electrophoretically from gels to polyvinylidene fluoride membranes, using $25 \mathrm{mmol}$ Tris- $\mathrm{HCl}$ litre ${ }^{-1}+192 \mathrm{mmol}_{\text {glycine }} \mathrm{1}^{-1}, \mathrm{pH} 8 \cdot 3,+15 \%$ methanol (modified from Towbin et al., 1979, and Burnette, 1981, as recommended by the manufacturer). Membranes were incubated for $1 \mathrm{~h}$ at room temperature in $20 \mathrm{mmol}$ Tris- $\mathrm{HCl}$ litre $^{-1}+0.15 \mathrm{~mol} \mathrm{NaCl}$ litre $^{-1}$, pH 7.4 (TNS), containing 5\% BSA $+5 \%$ non-fat dry milk to block nonspecific binding. Membranes were washed in TNS and incubated overnight at $4{ }^{\circ} \mathrm{C}$ with rabbit antibovine adrenocortical P-450 $0_{\mathrm{scC}}$ or antiporcine testicular $\mathrm{P}-450_{17 \mathrm{a}}$ antiserum diluted in TNS containing $0.05 \%$ Tween-20. Use of these antisera to quantitate the enzymes in rat and mouse Leydig cells has been validated by Payne and colleagues (Anakwe \& Payne, 1987; Georgiou et al., 1987; Perkins \& Payne, 1988; Hales \& Payne, 1989). Membranes were washed with TNS containing $0.05 \%$ Tween-20, and bound antibodies were labelled by incubation for $3 \mathrm{~h}$ at $4{ }^{\circ} \mathrm{C}$ with ${ }^{125}$ I-labelled protein $\mathrm{A}$ (prepared by the chloramineT reaction and Sephadex G-25 chromatography). Membranes were then washed, dried and exposed to Kodak XOmat AR film with Cronex intensifying screens at $-70^{\circ} \mathrm{C}$. Autoradiograms were developed with Ilford Bromophen developer.

\section{Apparatus, supplies and reagents}

Intra-atrial cannulae were made of medical grade Silastic tubing (i.d. 0.025 inches; o.d. 0.047 inches; from Dow Corning Corp., Midland, MI, USA). Infusion pumps were model A99 from Razel Scientific Instruments, Inc. (Stamford, CT, USA). Electronic timers were model T1975 from Intramatic, Inc. (Spring Grove, IL, USA) with circuits and relays from Allied Electronics, Inc. (Elgin, IL, USA). Ketamine-HCl was Ketaset from Bristol Labs (Syracuse, NY, USA). Xylazine and penicillin-G were obtained from Sigma Chemical Co. (St Louis, MO, USA). The LH preparation used in these experiments was NIDDK ovine LH-24 (biological potency $=2 \cdot 3 \times$ NIH-LH-S1). Human chorionic gonadotrophin (hCG; $3000 \mathrm{iu} \mathrm{mg}^{-1}$ ), fatty-acid-free BSA, Hepes, Percoll, neutral chromatographic aluminium oxide (type WN-9), chloramine-T, Dulbecco's modified Eagle's medium, and Ham's nutrient mixture F12 were obtained from Sigma. Tissue culture medium 199 was from Gibco (Grand Island, NY, USA). Collagenase (type A) and dithiothreitol were obtained from Boehringer Mannheim Biochemicals (Indianapolis, IN, USA). Acrylamide 
$(4 \times$ recrystallized), sodium cholate and sodium dodecyl sulfate were obtained from Serva Biochemicals (Westbury, NY, USA). $N, N^{\prime}$-methylene-bisacrylamide was from Aldrich Chemical Co., Inc. (Milwaukee, WI, USA). Glycine, protein A, tris(hydroxymethyl)-aminomethane (Tris), sucrose, bromphenol blue, and Tween-20 were obtained from Fisher Scientific Co. (Fair Lawn, NJ, USA). Sephadex G-25 was from Pharmacia Inc. (Piscataway, NJ, USA). Cronex intensifying screens, carrier-free $\mathrm{Na}^{125} \mathrm{I},\left[7-{ }^{3} \mathrm{H}\right]$-pregnenolone $\left(25 \mathrm{Ci} \mathrm{mmol}^{-1}\right), \quad\left[1,2-{ }^{3} \mathrm{H}\right]$-progesterone $(55 \mathrm{Ci}$ $\left.\mathrm{mmol}^{-1}\right),\left[26,27-{ }^{3} \mathrm{H}\right]-25$-hydroxycholesterol $\left(87 \mathrm{Ci} \mathrm{mmol}^{-1}\right)$, and $\left[4-{ }^{14} \mathrm{C}\right]$-progesterone, $-17 \alpha$-hydroxy-progesterone, -androstenedione, and -testosterone $\left(50-60 \mathrm{mCi} \mathrm{mmol}^{-1}\right)$ were purchased from DuPont-New England Nuclear (Boston. MA, USA). Radiolabelled steroids were repurified by thin-layer chromatography before use. $\left[{ }^{14} \mathrm{C}\right]-\mathrm{Caproic}$ acid was obtained from Research Products International Corp. (Mt Prospect, IL, USA). Nonradioactive steroids were obtained from Sigma, except for 25-hydroxycholesterol, which was from Steraloids, Inc. (Wilton, NH, USA). All organic solvents were high-performance liquid chromatography grade obtained from Baker Chemical Co. (Phillipsburg, NJ, USA), except for the following: diethyl ether was anaesthetic grade from Baker; dimethylsulfoxide was spectrophotometric grade from Aldrich and toluene was 'scintanalysed' from Fisher. Liquid scintillation cocktails were ScintiVerse E (Fisher) for aqueous samples and Liquifluor (DuPont-NEN) for spots from thin-layer chromatograms. Thin-layer chromatography of steroids was on ITLC-SA sheets from Gelman Scientific Co. (Ann Arbor, MI, USA). Polyvinylidene fluoride membranes were Immobilon P from Millipore Corp. (Bedford, MA, USA). Rabbit antisera against bovine adrenocortical $\mathrm{P}-450_{\mathrm{SCC}}$ and porcine testicular $\mathrm{P}-450_{17 a}$ were gifts from $\mathrm{A}$. $\mathrm{H}$. Payne (University of Michigan, Ann Arbor, MI, USA). Rabbit antiserum for testosterone radioimmunoassay was from G. M. Connell (Berkeley, CA, USA).

\section{Statistical analyses}

Analyses were carried out using analysis of variance and Newman-Keul's test after logarithmic transformation of data. Results are depicted as mean \pm SEM and values for a given variable that are significantly different among groups $(P=0.05)$ are denoted by different lower-case letters. There were six or seven animals in each group.

\section{Results}

Treatment with anti-GnRH serum reduced basal and maximum hormone-stimulated and substrate-supported testosterone production by $80-90 \%$; concurrent infusion of LH in any of the three regimens prevented these reductions in steroidogenic activity or increased the activity to values even greater than those in normal serum-treated controls (Fig. 1). Although not all the differences among groups of LH-treated rats were statistically significant, there was a consistent trend for the effectiveness of $\mathrm{LH}$ replacement regimens in maintaining steroidogenic activity to vary directly with frequency (inversely with amplitude) of LH administration (i.e. continuous infusions were more effective than pulses at $2 \mathrm{~h}$ intervals and these in turn were more effective than pulses at $4 \mathrm{~h}$ intervals). Testosterone production stimulated by hCG and supported by 25hydroxycholesterol was significantly greater than basal in all treatment groups. Testosterone production stimulated by hCG was significantly less than that supported by 25 -hydroxycholesterol in anti-GnRH-treated rats given saline or LH pulses, but not in normal serum-treated controls or in anti-GnRH-treated rats given continuous infusions of LH. Differences in the two modes of testosterone production were also apparent in the ratios of substrate-supported to hormonestimulated production (Table 1).

Activities of the two cytochrome P-450 enzymes, cholesterol side-chain cleavage and $17 \alpha$ hydroxylase, differed among groups in the same pattern as testosterone production supported by 25-hydroxycholesterol, but the decrease in side-chain cleavage activity after anti-GnRH treatment (about $80 \%$ ) was greater than that in $17 \alpha$-hydroxylase activity (about 65\%) (Fig. 2). Differences in the activities of the P-450 enzymes were accompanied by parallel differences in the contents of immunodetectable enzyme proteins (Fig. 3).

Activity of the non-P-450 enzyme, $3 \beta$-HSD-isomerase, also decreased after 5 days of treatment with anti-GnRH serum (Fig. 4), but not as much as did the activities of the P-450 enzymes (only about $40 \%$ ). All of the $\mathrm{LH}$ treatment regimens prevented this decrease in enzyme activity or increased the activity to values even greater than those in control rats treated with normal serum (Fig. 4). There was no consistent pattern in the effects of the different LH regimens on this enzyme activity. 


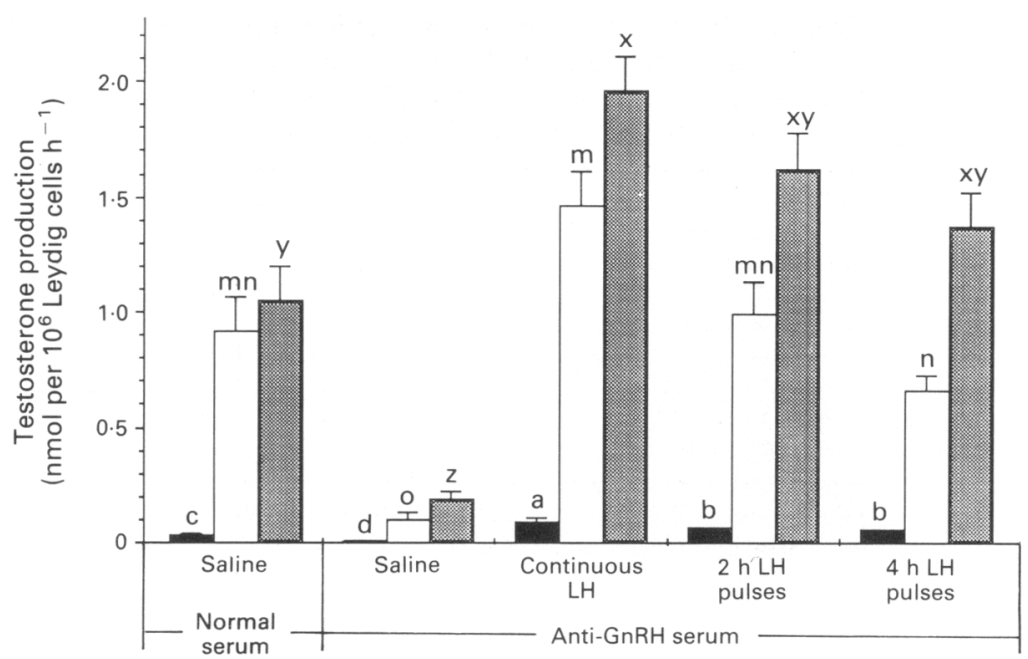

Fig. 1. Testosterone production: basal ( $\boldsymbol{\square})$, stimulated by human chorionic gonadotrophin ( $\square$ ) and supported by 25-hydroxycholesterol (圈) in Leydig cells from rats treated for 5 days with normal serum or with antigonadotrophin-releasing hormone serum and vehicle ('saline') or luteinizing hormone $(\mathrm{LH})$, given as continuous infusions of $12.5 \mathrm{ng}$ per $100 \mathrm{~g} \mathrm{~h}^{-1}$ (continuous $\mathrm{LH}$ ) or as 1-min pulses of $25 \mathrm{ng}$ per $100 \mathrm{~g}$ every $2 \mathrm{~h}$ ( 2 -h LH pulses) or $50 \mathrm{ng}$ per $100 \mathrm{~g}$ every $4 \mathrm{~h}$ (4-h LH pulses). Data are depicted as mean $\pm \operatorname{SEM}(n=6-7$ per group). For a given mode of testosterone production, values with different lower-case letters are significantly different $(P<0.05)$ among treatment groups. Different lower-case letters for different modes of testosterone production within a treatment group do not imply statistically significant differences.

\section{Discussion}

Previous studies in our laboratory have shown that maintenance of testosterone-producing capacity stimulated by hormone or second messenger or supported by substrate in Leydig cells can be accomplished with continuous i.v. infusions of exogenous $\mathrm{LH}$ as well as with infusions of $\mathrm{LH}$ pulses delivered every $2 \mathrm{~h}$ during passive immunization against GnRH. Since steroid hormone production is not generally limited by the activities of the enzymes that convert cholesterol to the secreted hormone, however, those results did not prove that maintenance of these enzymes is also independent of the mode of LH administration (pulsatile versus continuous). The present results show that to be the case for at least three of the four enzymes involved in testosterone production from cholesterol in rat Leydig cells: the mitochondrial and microsomal cytochrome P-450 enzymes, cholesterol side-chain cleavage and $17 \alpha$-hydroxylase, and the microsomal non-P-450 enzyme $3 \beta$-HSD-isomerase. The activities and immunodetectable contents of both of the cytochrome P-450 enzymes decreased markedly during 5 days of anti-GnRH treatment and these decreases were prevented by all the LH infusion regimens tested. The dependence of both cytochrome P- 450 enzymes on $\mathrm{LH}$ in this model contrasts with the high constitutive synthesis of P-450 scC $_{\text {in }}$ cultured mouse Leydig cells (Anakwe \& Payne, 1987; Hales \& Payne, 1989). Whether this reflects a difference between species or the presence of an inhibitor in vivo (the action of which is suppressed by $\mathrm{LH}$ ) remains to be determined. The activity of $3 \beta-\mathrm{HSD}$-isomerase did not decrease nearly as much during anti-GnRH treatment, but it was increased by concurrent infusion of LH in all of the regimens. The relative lack of dependence of $3 \beta-\mathrm{HSD}$-isomerase on $\mathrm{LH}$ in this model is in good accord with results from studies in which $\mathrm{LH}$ secretion was suppressed by implantation of Silastic capsules containing testosterone and oestradiol (Wing et al., 1985; Keeney et al., 1988).

The last of the enzymes involved in testosterone production, 17-ketosteroid reductase, which catalyses the conversion of androstenedione to testosterone, has received much less attention than 
Table 1. Ratio of testosterone production supported by 25 -hydroxycholesterol (A) to that stimulated by human chorionic gonadotrophin (B) in Leydig cells from rats treated as described in the legend to Fig. 1

\begin{tabular}{lc}
\hline Treatment & $\mathrm{A}: \mathrm{B}$ \\
\hline $\begin{array}{l}\text { Normal serum } \\
\quad+\text { saline }\end{array}$ & $1 \cdot 17 \pm 0 \cdot 14^{\mathrm{c}}$ \\
Anti-GnRH serum & $2 \cdot 32 \pm 0 \cdot 31^{\mathrm{a}}$ \\
$\quad$ + saline & $1 \cdot 37 \pm 0.07^{\mathrm{bc}}$ \\
$\quad$ continuous LH & $1.69 \pm 0.09^{\mathrm{ab}}$ \\
$\quad$ +2h pulses of LH & $2 \cdot 14 \pm 0.21^{\mathrm{a}}$ \\
\hline
\end{tabular}

Results are given as mean \pm SEM; values with different superscript letters are significantly different $(P<0.05)$.

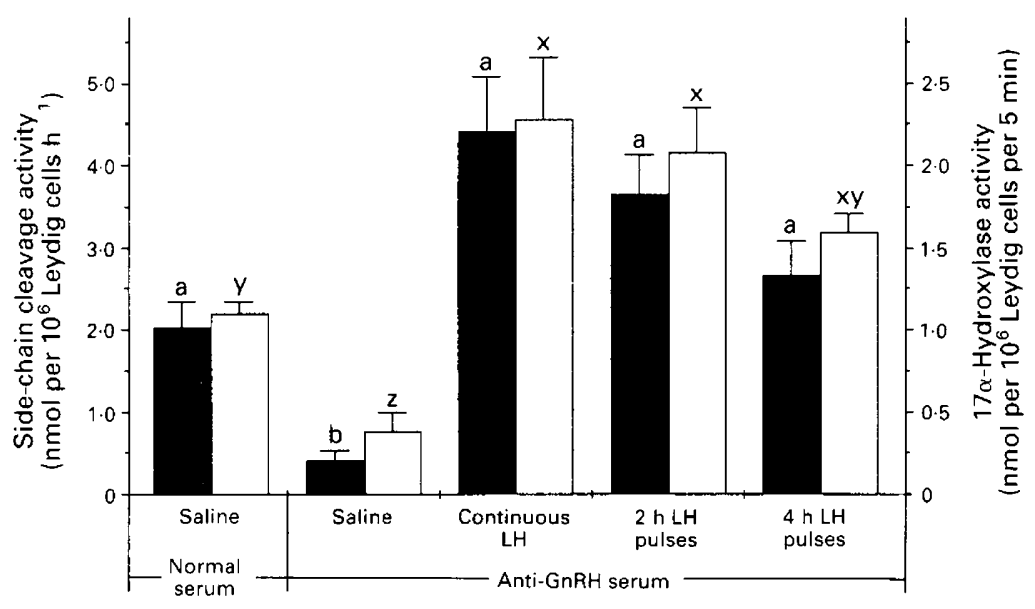

Fig. 2. Cholesterol side-chain cleavage ( $\square$ ) and $17 \alpha$-hydroxylase ( $\square$ ) activities in Leydig cells from rats treated as indicated in Fig. 1. The $y$ axes for the two enzymes are drawn to different scales.

the preceding enzymes. Treatment with hCG in vivo has been reported to reduce its activity in rat Leydig cells (O'Shaughnessy \& Payne, 1982), suggesting that it is subject to different regulation from the other enzymes and would be worth examining in the model described here.

The differences among $\mathrm{LH}$ infusion groups in testosterone production and cytochrome P-450 enzyme activities showed a consistent trend: continuous infusions were more effective than pulses at $2 \mathrm{~h}$ intervals and these in turn were more effective than pulses at $4 \mathrm{~h}$ intervals. This trend suggests that the frequency of LH exposure is more important than the amplitude of individual exposures in maintaining Leydig cell steroidogenic function. Studies are now in progress to confirm this and to rule out the possibility that an apparent relative inefficacy of low-frequency, high-amplitude LH pulses (in infusion regimens delivering a fixed daily dosage of hormone) is due to a negative effect of the high amplitude (similar to the well-known steroidogenic desensitization caused by supraphysiological doses of $\mathrm{LH}$ or $\mathrm{hCG}$ ) rather than to a lesser positive effect of the low frequency.

Perhaps the most interesting component of the data presented here is the consistent trend in the differences between hCG-stimulated and 25-hydroxycholesterol-supported testosterone 
(a)
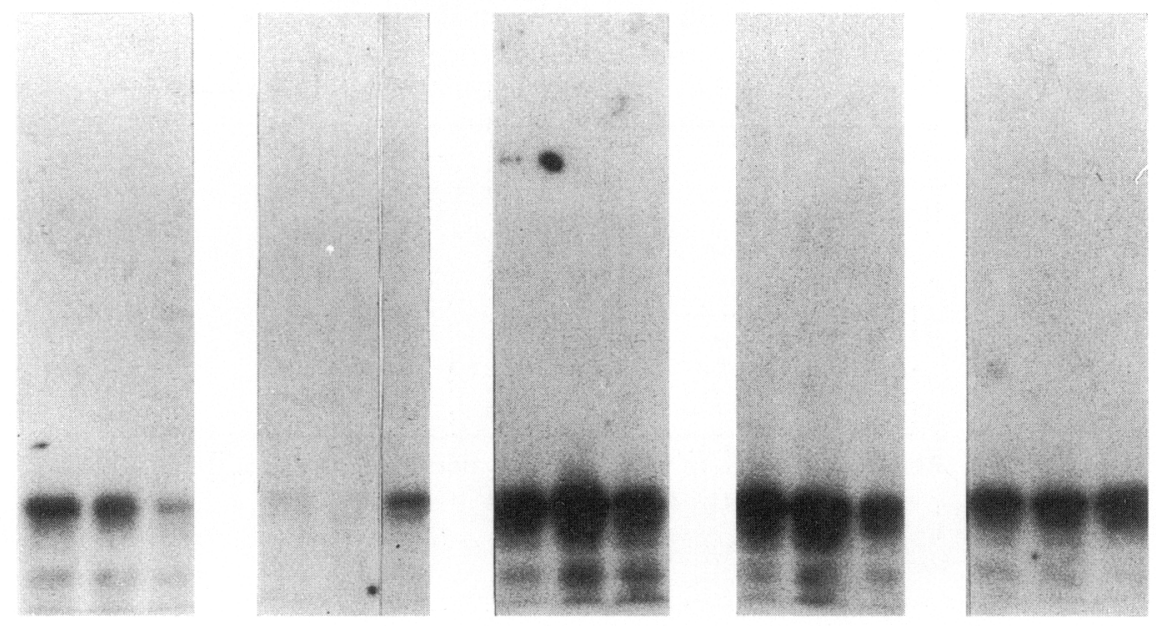

(b)

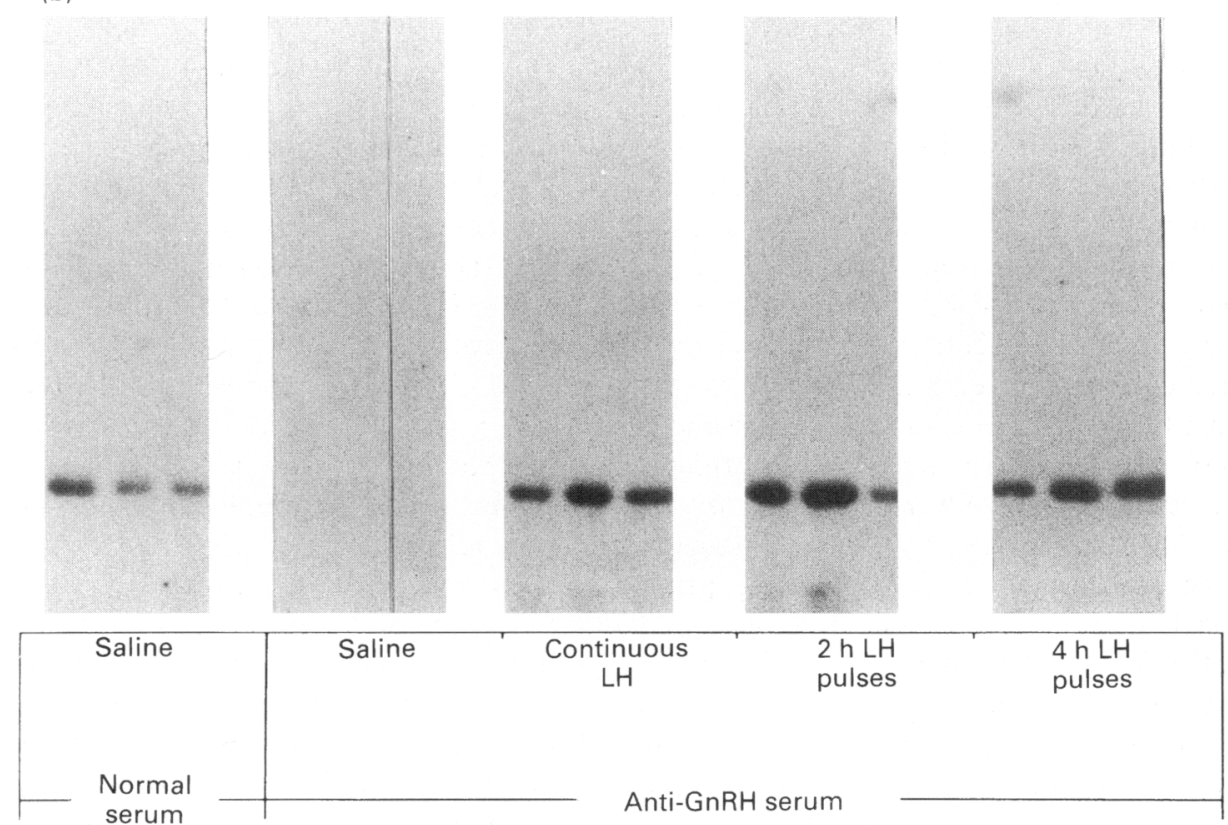

Fig. 3. Autoradiograms of western blots of Leydig cell lysates immunolabelled for (a) P-450

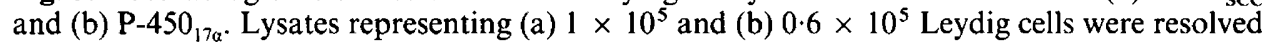
electrophoretically in $10 \%$ acrylamide gels, transferred to polyvinylidine fluoride membranes and labelled sequentially with anti-P-450 $\mathrm{scc}_{\text {or }}$ or anti-P-450 $0_{17 \mathrm{a}}$ and ${ }^{125} \mathrm{I}$-protein $\mathrm{A}$. Lanes representing Leydig cells from three rats from each experimental group, which were processed together, are shown.

production among groups. In normal serum-treated control animals, the ability of Leydig cells to produce testosterone from endogenous substrate under the influence of $\mathrm{hCG}$ was almost as great as their ability to produce testosterone from exogenous 25 -hydroxycholesterol. In anti-GnRH-treated animals given no LH replacement, in contrast, the capacity to produce testosterone from 25 hydroxycholesterol averaged more than twice the capacity to produce testosterone from endo- 


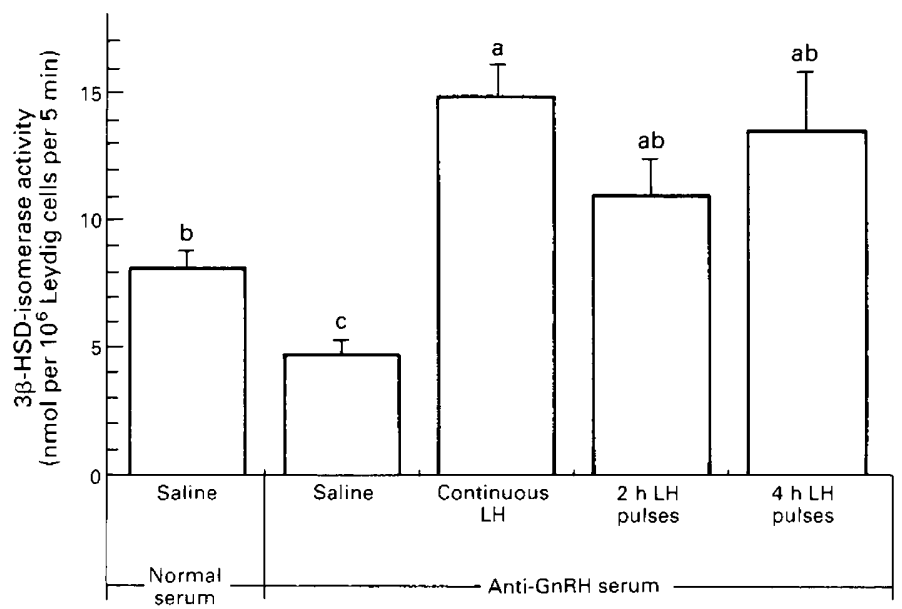

Fig. 4. $\Delta^{5}-3 \beta$-hydroxysteroid dehydrogenase- $\Delta^{5-4}$-isomerase ( $3 \beta$-HSD-isomerase) activity in Leydig cells from rats treated as indicated in Fig. 1.

genous substrate in response to hCG stimulation. The better an $\mathrm{LH}$ infusion regimen was at maintaining steroidogenic capacity and cytochrome P-450 enzyme activities, the better it was at maintaining the capacity to respond to hCG stimulation at values near exogenous substratesupported testosterone production. Such differences and trends were not apparent after $\mathrm{LH}$ secretion was suppressed for 5 days more than in the present experiments: after 10 days of passive immunization against GnRH, 25-hydroxycholesterol-supported testosterone production was reduced as severely as was hCG-stimulated production (Gibson-Berry \& Chase, 1990). Taken together, the data suggest that some constituent(s) of Leydig cells before cholesterol side-chain cleavage enzyme is (are) more sensitive to withdrawal of LH and deviations from 'optimal' $\mathrm{LH}$ exposure than are the side-chain cleavage and subsequent enzymes in the testosterone biosynthetic pathway. LH receptors can probably be ruled out on the basis that ${ }^{125} \mathrm{I}$-hCG-binding capacity of Leydig cells is not significantly altered by 10 days of anti-GnRH treatment (Gibson-Berry \& Chase, 1990). Fragmentary data have suggested that the following might all be subject to longterm regulation by $\mathrm{LH}: \mathrm{LH}$ receptor-G-protein-adenylate cyclase coupling (Dix et al., 1982; Schumacher et al., 1984); 3-hydroxy-3-methylglutaryl-coenzyme A reductase (Charreau et al., 1981 ), the rate-limiting enzyme in cholesterol biosynthesis; and sterol carrier protein 2 (van Noort et al., 1986) and steroidogenesis activator polypeptide (Pedersen, 1987), two of the factors implicated in transport of cholesterol to the side-chain cleavage enzyme or association of the substrate with the enzyme's active site in the inner mitochondrial membrane. Systematic studies using the model described here are in progress to determine whether LH receptor-G-protein-adenylyl cyclase coupling, cyclic AMP-generating capacity, cholesterol content and mechanisms involved in delivery of cholesterol to cholesterol side-chain cleavage enzyme are subject to long-term regulation by $\mathrm{LH}$ and are more dependent on and sensitive to trophic actions of the hormone than are the enzymes involved directly in the synthesis of testosterone from cholesterol.

The authors are grateful for the generous gifts of anti-cytochrome P-450 antibodies from A. H. Payne (University of Michigan), anti-testosterone antibody from G. M. Connell (Berkeley, CA) and ovine LH from the National Hormone and Pituitary Program (supported by the National Institutes of Health, USA). This work was presented at the 1989 Annual Conference of the Society for the Study of Fertility, University of Kent, Canterbury, UK and is abstracted in Journal of Reproduction and Fertility, Abstract Series No. 3, p. 27. This research was supported by grants from the National Institutes of Health, USA (HD-22997 and RR-07149). 


\section{References}

Anakwe, O.O. \& Payne, A.H. (1987) Noncoordinate regulation of de novo synthesis of cytochrome $\mathbf{P} 450$ cholesterol side-chain cleavage and cytochrome $\mathbf{P} 450$ $17 \alpha$-hydroxylase/C17-20 lyase in mouse Leydig cell cultures. Molecular Endocrinology 1, 595-603.

Burnette, W.N. (1981) 'Western blotting': electrophoretic transfer of proteins from sodium dodecyl sulfatepolyacrylamide gels to unmodified nitrocellulose and radiographic detection with antibody and radioiodinated protein A. Analytical Biochemistry 112, 195-203.

Charreau, E.H., Calvo, J.C., Nozu, K., Pignataro, O., Catt, K.J. \& Dufau, M.L. (1981) Hormonal modulation of 3-hydroxy-3-methylglutaryl coenzyme A reductase activity in gonadotropin-stimulated and -desensitized testicular Leydig cells. Journal of Biological Chemistry 256, 12 719-12 724.

Chase, D.J., Schanbacher, B.D. \& Lunstra, D.D. (1988) Effects of pulsatile and continuous luteinizing hormone ( $\mathrm{LH}$ ) infusions on testosterone responses to LH in rams actively immunized against gonadotropinreleasing hormone. Endocrinology 123, 816-826.

Dix, C.J., Schumacher, M. \& Cooke, B.A. (1982) Desensitization of tumour Leydig cells by lutropin: evidence for uncoupling of the lutropin receptor from the guanine nucleotide-binding protein. Biochemical Journal 202, 739-745.

Ewing, L.L., Wing, T.-Y., Cochran, R.C., Kromann, N. \& Zirkin, B.R. (1983) Effect of luteinizing hormone on Leydig cell structure and testosterone secretion. Endocrinology 112, 1763-1769.

Georgiou, M. \& Payne, A.H. (1985) 25-Hydroxycholesterolsupported and 8-bromo-adenosine-3', ' $^{\prime}$-monophosphate-stimulated testosterone production by primary cultures of two populations of rat Leydig cells. Endocrinology 117, 1 184-1188.

Georgiou, M., Perkins, L.M. \& Payne, A.H. (1987) Steroid synthesis-dependent, oxygen-mediated damage of mitochondrial and microsomal cytochrome P-450 enzymes in rat Leydig cell cultures. Endocrinology 121, 1390-1399.

Gibson-Berry, K.L. \& Chase, D.J. (1990) Continuous and pulsatile infusions of luteinizing hormone have identical effects on steroidogenic capacity and sensitivity of Leydig cells in rats passively immunized against gonadotropin-releasing hormone. Endocrinology 126, 3107-3115.

Hales, D.B. \& Payne, A.H. (1989) Glucocorticoidmediated repression $\mathrm{P} 450_{\text {scc }} \mathrm{mRNA}$ and de novo synthesis in cultured Leydig cells. Endocrinology 124, 2099-2104.

Hall, P.F. (1986) Cytochromes P-450 and the regulation of steroid synthesis. Steroids 48, 133-196.

Keeney, D.S., Mendis-Handagama, S.M.L.C., Zirkin, B.R. \& Ewing, L.L. (1988) Effect of long-term deprivation of luteinizing hormone on Leydig cell volume, Leydig cell number, and steroidogenic capacity of the rat testis. Endocrinology 123, 29062915.

Menon, K.M.J., Dorfman, R.I. \& Forchielli, E. (1967) Influence of gonadotropins on the cholesterol sidechain cleavage reaction by rat testis mitochondrial preparations. Biochimica Biophysica Acta 148, $486-494$.
Murono, E.P. \& Payne, A.H. (1979) Testicular maturation in the rat. In vivo effect of gonadotropins on steroidogenic enzymes in the hypophysectomized immature rat. Biology of Reproduction 20, 911-917.

O'Shaughnessy, P.J. \& Payne, A.H. (1982) Differential effects of single and repeated administration of gonadotropins on testosterone production and steroidogenic enzymes in Leydig cell populations. Journal of Biological Chemistry 257, 11 503-11 509.

O'Shaughnessy, P.J., Wong, K.-L. \& Payne, A.H. (1981) Differential steroidogenic enzyme activities in different populations of rat Leydig cells. Endocrinology 109, 1061-1066.

Pedersen, R.C. (1987) Steroidogenesis activator polypeptide (SAP) in the rat ovary and testis. Journal of Steroid Biochemistry 27, 731-735.

Perkins, L.M. \& Payne, A.H. (1988) Quantification of $\mathrm{P} 450_{\mathrm{SCC}}, \mathrm{P} 450_{179}$, and iron sulfur protein reductase in Leydig ceils and adrenals of inbred strains of mice. Endocrinology 123, 2675-2682.

Purvis, J.L., Canick, J.A., Rosenbaum, J.H., Hollogitas, J. \& Latif, S.A. (1973a) Control of cytochrome P-450 in rat testis mitochondria by human chorionic gonadotropin. Archives of Biochemistry and Biophysics 159, 32-38.

Purvis, J.L., Canick, J.A., Latif, S.A., Rosenbaum, J.H., Hollogitas, J. \& Menard, R.H. (1973b) Lifetime of microsomal cytochrome P-450 and steroidogenic enzymes in rat testis as influenced by human chorionic gonadotropin. Archives of Biochemistry and Biophysics 159, $39-49$.

Quinn, P.G., Georgiou, M. \& Payne, A.H. (1985) Differences in the control of sterol metabolism between mouse and rat Leydig cells. Endocrinology 116, 2300-2305.

Samuels, L.T. \& Helmreich, M.L. (1956) The influence of chorionic gonadotropin on the $3 \beta$-ol dehydrogenase activity of testes and adrenals. Endocrinology 58, 435-442.

Schumacher, M., Schwarz, M. \& Brandle, W. (1984) Desensitization of the cAMP system in mouse Leydig cells by hCG, cholera toxin, dibutyryl cAMP and cAMP: localization of the "lesion" to the guanine nucleotide regulatory protein-adenylate cyclase complex. Molecular and Cellular Endocrinology 34, 67-80.

Shaw, M.J., Georgopoulos, L.E. \& Payne, A.H. (1979) Synergistic effect of follicle-stimulating hormone and luteinizing hormone on testicular $\Delta 5$-3 $\beta$-hydroxysteroid dehydrogenase-isomerase: application of a new method for the separation of testicular compartments. Endocrinolog. 104, 912 918.

Shikita, M. \& Hall, P.F. (1967) Action of human chorionic gonadotropin in vivo upon microsomal enzymes in testes of hypophysectomized rats. Biochimica Biophisica Acta 141, 433-435.

Toaff, M.E., Strauss III, J.F., Flickinger, G.L. \& Shattil, S.J. (1979) Relationship of cholesterol supply to luteal mitochondrial steroid synthesis. Journal of Biological Chemistry 254, 3977-3981.

Toaff, M.E., Schleyer, H. \& Strauss III, J.F. (1982) Metabolism of 25-hydroxycholesterol by rat luteal mitochondria and dispersed cells. Endocrinology 111, $1785-1790$ 
Towbin, H., Staehelin, T. \& Gordon, J. (1979) Electrophoretic transfer of proteins from polyacrylamide gels to nitrocellulose sheets: procedure and some applications. Proceedings of National Academy of Sciences, USA 76, 4350-4354.

van Noort, M., Rommerts, F.F.G., van Amerongen, A. \& Wirtz, K.W.A. (1986) Localization and hormonal regulation of the non-specific lipid transfer protein (sterol carrier protein ${ }_{2}$ ) in the rat testis. Journal of Endocrinology 109, R13-R16.
Waterman, M.R. \& Simpson, E.R. (1989) Regulation of hydroxylase gene expression is multifactorial in nature. Recent Progress in Hormone Research 45, $533-563$.

Wing, T.-Y., Ewing, L.L., Zegeye, B. \& Zirkin, B.R. (1985) Restoration effects of exogenous luteinizing hormone on the testicular steroidogenesis and Leydig cell ultrastructure. Endocrinology 117, 1779-1787.

Received 8 May 1991 